\title{
36. DIAGENETIC EVOLUTION OF NEOGENE VOLCANIC ASHES (CELEBES AND SULU SEAS)1
}

\author{
Alain Desprairies, ${ }^{2}$ Marc Rivière, ${ }^{2}$ and Manuel Pubellier ${ }^{3}$
}

\begin{abstract}
Mineralogical and geochemical analyses were performed on 40 ash layers of Pleistocene to late Miocene age, recovered during Leg 124 in the Celebes and Sulu Seas (Sites 767, 768, and 769). They provide information on alteration processes related to burial diagenesis. The zonal distribution of secondary volcanic products emphasizes a major diagenetic change, characterized by the complete replacement of volcanic glass by an authigenic smectite-phillipsite assemblage, in tephra layers dated at 3.5-4 Ma. This diagenetic "event" occurs simultaneously in the two basins, and, on the basis of isotopic data, under low-temperature conditions. It is independent of distinct sedimentation rates and related to a relative quiescence of on-land volcanic activity. This period suggests a more uniform paleooceanographic situation having tectonic significance, and probably reflects a kinetic and environmental control of diagenetic reactions.
\end{abstract}

\section{INTRODUCTION}

During ODP Leg 124, tephra ranging in age from middle Eocene to Quaternary were recovered from five holes in the Celebes and Sulu Seas (Rangin, Silver, von Breymann, et al., 1990). Middle Eocene to early Miocene ash beds are scattered in brownish pelagic claystones from the Celebes Sea (Site 767). Late, early Miocene pyroclastic flows occur only in the Sulu Sea (Sites 768 and 769). In both basins, middle Miocene time is a period of quiescence of volcanic activity, and no discrete ash layers are recognizable in hemipelagic claystones. The last period of Cenozoic explosive volcanism extends from late Miocene (about $8 \mathrm{Ma}$ ) to the present with an apparent lack of volcaniclastic material centered on $3 \mathrm{Ma}$ (Pubellier et al., this volume; Pouclet et al., this volume).

We only considered in this paper air-fall ash deposits of Pleistocene to late Miocene age. The frequency of ash-layer decreases markedly during the Pliocene and may record either a gap in the on-land plinian volcanic activity, dilution by sedimentary processes, and/or progressive vanishing of primary volcanic components by diagenetic effects. Andesitic to rhyolitic glasses altered to clay were frequently reported on shipboard smear-slide descriptions (Rangin, Silver, von Breymann, et al., 1990). Our purpose is to specify both the nature of secondary volcanic products and their location within the Neogene ash distribution as a result of diagenetic processes that emphasize the geodynamic evolution of Celebes and Sulu seas.

\section{METHODOLOGY AND ANALYTICAL PROCEDURES}

Forty discrete ash layers were chosen (Table 1) as representative of lithologic Units I and II from Sites 768 and 769 (Sulu Sea) and 767 (Celebes Sea). Mineralogical and chemical analyses were performed on bulk samples, silt (35-63 $\mu \mathrm{m})$ and clay $(<2 \mu \mathrm{m})$ fractions separated by sieving or centrifuging and cleaned by ultrasonic methods. Two X-ray diffraction methods (randomly oriented and suspension sedimented sam-

\footnotetext{
${ }^{1}$ Silver, E. A., Rangin, C., von Breymann, M. T., et al., 1991. Proc. ODP, Sci. Results, 124: College Station, TX (Ocean Drilling Program).

2 Université de Paris Sud - Laboratoire de Géochimie des Roches Sédimentaires - Bât. 504 - 91405 Orsay, France.

${ }^{3}$ Université Pierre et Marie Curie - Laboratoire de Géotectonique T26. O- 75252 Paris, France.
}

ples) were used for mineralogical determinations. ${ }^{4}$ Majorelement compositions of bulk sample, coarse and fine fractions, or single separate particles were determined either by electron microprobe (EM) or by scanning electron microprobe (SEM) fitted with an energy dispersive spectrometer. ${ }^{5}$ Each technique has advantages and drawbacks. For the EM work, the major problem is the loss of alkalis under beam, especially $\mathrm{Na}$. We analyzed scanning areas of $25-100 \mu \mathrm{m}^{2}$ considering the size of the particles. The EM used was a CAMEBAX-type automated microprobe with TRACOR system, working under $15 \mathrm{kV}$ and $5 \mathrm{nA}$. Under these conditions and with a counting time of $5 \mathrm{~s}$, the detection limit of major elements is ca. $0.3 \%$ with analytical precisions better than $5 \%$. The lack of important alkali loss was checked by a CIPW norm calculation on glass analyses (lack or scarcity of normative corundum). For the SEM/EDS (energy dispersive spectrometry) studies, large scanning areas $\left(100 \mu \mathrm{m}^{2}\right)$ were analyzed under $15 \mathrm{kV}$ with real-time acquisition of $120 \mathrm{~s}$. Under these conditions, no significant loss of alkalis was observed. The relative errors are less than $3 \%$ for elements with concentrations between $5 \%$ and $10 \%$, and $20 \%$ for elemental concentrations $<5 \%$. The detection limit is $0.1 \%$. The weight deficit to $100 \%$ is often unrelated to water content. Therefore the results for clay minerals were recalculated to $100 \%$ (oxide values in percent by weight, in a water-free basis). To allow for comparison with EM, data were normalized to $90 \%$ for zeolites, $95 \%$ and $97 \%$ for silicic and basic glasses, respectively, and to $98 \%$ for K-feldspars.

Oxygen isotope analyses have been made on authigenic phillipsite and smectite extracted from bulk altered-ash samples and on a variety of mixed fresh-glass/altered-glass, and authigenic zeolite/clay assemblages. Oxygen was liberated from samples by reacting with $\mathrm{BrF}_{5}$ and then converted to $\mathrm{CO}_{2}$ for mass spectrometric analysis following the procedure described by Clayton and Mayeda (1963). Phillipsite was left 5 days in a drybox before analysis to eliminate the effect of ${ }^{18} \mathrm{O}$ composition of zeolitic water (Savin and Epstein, 1970b). Analytical precision was generally $\pm 0.5 \%$ o (average deviation).

Finally, at each Site, the ash layers were dated using biostratigraphic markers and extrapolation between markers

\footnotetext{
${ }_{5}^{4}$ (XRD INEL with curved position sensitive detector CPS 120).

5 (SEM PHILIPS 505 with LINCK System).
} 
Table 1. Location and age of studied ash-layers samples. Tephra are dated using biostratigraphic markers and according to the sedimentation rates (Rangin, Silver, von Breymann, et al., 1990).

\begin{tabular}{|c|c|c|c|c|c|c|c|c|c|c|c|c|c|c|c|c|c|}
\hline Hole & Core & Sect. & $\begin{array}{l}\text { Interval } \\
(\mathrm{cm})\end{array}$ & $\begin{array}{l}\text { Depth } \\
\text { (mbsf) }\end{array}$ & $\begin{array}{l}\text { Age } \\
(\mathrm{Ma})\end{array}$ & Hole & Core & Sect. & $\begin{array}{c}\text { Interval } \\
(\mathrm{cm})\end{array}$ & $\begin{array}{l}\text { Depth } \\
\text { (mbsf) }\end{array}$ & $\begin{array}{l}\text { Age } \\
(\mathrm{Ma})\end{array}$ & Hole & Core & Sect. & $\begin{array}{c}\text { Interval } \\
(\mathrm{cm})\end{array}$ & $\begin{array}{l}\text { Depth } \\
\text { (mbsf) }\end{array}$ & $\begin{array}{l}\text { Age } \\
\text { (Ma) }\end{array}$ \\
\hline 767B & $1 \mathrm{H}$ & 6 & $124-126$ & 8.74 & 0.088 & $768 \mathrm{~A}$ & $1 \mathrm{H}$ & 5 & $069-071$ & 6.67 & 0.070 & $769 \mathrm{~B}$ & $2 \mathrm{H}$ & 2 & $068-070$ & 7.58 & 0.076 \\
\hline 767B & $4 \mathrm{H}$ & 6 & $041-043$ & 35.91 & 0.362 & $768 \mathrm{~B}$ & $4 \mathrm{H}$ & 5 & $014-016$ & 29.14 & 0.287 & $769 \mathrm{~B}$ & $4 \mathrm{H}$ & 2 & $130-132$ & 27.20 & 0.273 \\
\hline 767B & $6 \mathrm{H}$ & 2 & 090-092 & 49.40 & 0.515 & $768 \mathrm{~B}$ & $7 \mathrm{H}$ & 4 & 097-099 & 56.97 & 0.584 & $769 \mathrm{~A}$ & $6 \mathrm{H}$ & 1 & $055-058$ & 46.96 & 0.488 \\
\hline 767B & $9 \mathrm{H}$ & 3 & $061-063$ & 75.11 & 0.960 & $768 \mathrm{~B}$ & $10 \mathrm{H}$ & 5 & $113-115$ & 87.13 & 1.222 & $769 \mathrm{~B}$ & $7 \mathrm{H}$ & 2 & $030-033$ & 54.70 & 0.686 \\
\hline 767B & $10 \mathrm{H}$ & 6 & $079-081$ & 89.29 & 1.309 & $768 \mathrm{~B}$ & $12 \mathrm{H}$ & 5 & $072-075$ & 105.72 & 1.615 & $769 \mathrm{~B}$ & $9 \mathrm{H}$ & 4 & $126-128$ & 77.66 & 1.271 \\
\hline 767B & $13 x$ & $\mathrm{CC}$ & $005-007$ & 119.15 & 1.752 & $768 \mathrm{~B}$ & $14 \mathrm{H}$ & 2 & $132-134$ & 120.82 & 2.001 & $769 \mathrm{~B}$ & $12 \mathrm{H}$ & 3 & $101-103$ & 104.41 & 2.350 \\
\hline 767B & $18 \mathrm{X}$ & 4 & $029-031$ & 162.79 & 2.510 & $768 \mathrm{~B}$ & $14 \mathrm{H}$ & 3 & $098-100$ & 121.98 & 2.061 & $769 \mathrm{~B}$ & $14 \mathrm{H}$ & 4 & $122-124$ & 125.12 & 3.357 \\
\hline 767B & $23 x$ & 1 & $054-056$ & 203.84 & 3.261 & $768 B$ & $18 \mathrm{H}$ & 6 & $052-053$ & 164.02 & 4.022 & $769 \mathrm{~B}$ & $15 \mathrm{H}$ & 2 & $020-022$ & 130.62 & 3.548 \\
\hline 767B & $26 \mathrm{X}$ & 5 & $044-046$ & 233.04 & 3.795 & $768 \mathrm{~B}$ & $18 \mathrm{H}$ & 6 & $053-054$ & 164.03 & 4.022 & $769 \mathrm{~B}$ & $15 \mathrm{H}$ & 2 & $056-058$ & 130.96 & 3.642 \\
\hline $767 \mathrm{~B}$ & $29 \mathrm{X}$ & 2 & $117-119$ & 273.67 & 4.539 & $768 \mathrm{~B}$ & $21 \mathrm{H}$ & 2 & $115-120$ & 185.98 & 4.869 & $769 \mathrm{~B}$ & $16 \mathrm{H}$ & 5 & $050-052$ & 144.90 & 4.268 \\
\hline 767B & $35 \mathrm{X}$ & 5 & $008-010$ & 325.48 & 5.686 & $768 \mathrm{~B}$ & $28 \mathrm{X}$ & 3 & $064-066$ & 242.24 & 5.954 & $769 \mathrm{~B}$ & $24 \mathrm{H}$ & 5 & $002-004$ & 217.32 & 9.134 \\
\hline 767B & $36 \mathrm{X}$ & 2 & $114-116$ & 331.74 & 5.880 & $768 \mathrm{~B}$ & $29 \mathrm{X}$ & 3 & $037-039$ & 251.67 & 6.137 & & & & & & \\
\hline 767B & $40 x$ & 1 & 007-009 & 367.87 & 7.000 & 768B & $33 X$ & 1 & $053-055$ & 287.33 & 6.828 & & & & & & \\
\hline 767B & $42 X$ & 6 & 094-098 & 395.53 & 7.859 & $768 \mathrm{~B}$ & $38 \mathrm{X}$ & 4 & $033-035$ & 339.93 & 7.848 & & & & & & \\
\hline 767B & $47 X$ & 1 & $054-056$ & 435.94 & 8.913 & & & & & & & & & & & & \\
\hline
\end{tabular}

according to the sedimentation rates (Rangin, Silver, von Breymann, et al., 1990).

\section{PETROGRAPHY OF ASH LAYERS}

Several types of assemblages consisting of primary and secondary volcanic components were distinguished through mineralogical and chemical analyses of ash layers. The occurrence of alteration products can be related to a zonal distribution within lithologic Units I and II from Sites 767, 768, and 769 (Fig. 1).

\section{Celebes Sea (Site 767)}

Tephra layers are present in two lithostratigraphic units (Rangin, Silver, von Breymann, et al., 1990).

Unit I (0-56.8 mbsf; Core 124-767B-1H through Section 124-767B-7H-1, $34 \mathrm{~cm}$ ) is Pleistocene to Holocene in age. It consists of volcanogenic clayey silts with sparse ash interbeds.

Unit II (56.8-406.5 mbsf; Section 124-767B-7H-1, $34 \mathrm{~cm}$ through Core 124-767B-43X) ranging from late Miocene to Pleistocene in age, is divided into three subunits.

Subunit IIA (56.8-109.6 mbsf; Section 124-767B-7H-1, 34 $\mathrm{cm}$ through Core 124-767B-11X) is Pleistocene in age. Volcanogenic clayed silt with rare interbeds of volcanic ash and carbonate turbidites is the dominant lithology.

Subunit IIB (109.6-300.1 mbsf; Cores 124-767B-13X through $-767 \mathrm{~B}-32 \mathrm{X}$ ) is early Pliocene to Pleistocene in age. Volcanogenic clayey silt is also dominant lithology. This subunit differs from subunit IIA in that carbonate turbidites are more abundant and discrete ash layers are almost completely absent (Rangin, Silver, von Breymann, et al., 1990).

Subunit IIC (300.1-406.5 mbsf; Cores 124-767B-33X through $-767 \mathrm{~B}-43 \mathrm{X}$ ) is late Miocene to early Pliocene in age. Volcanogenic silty claystone contains less abundant carbonate turbidites and more tuff beds compared to Subunit IIB.

The spatial distribution of diagenesis, compared to lithostratigraphic units, is as follows (Table 2):

\section{Zone I "Fresh Glass"}

Unaltered zone (0-71.5 mbsf; Cores 124-767B-1H through $-8 \mathrm{H})$. Tephra layers consist mainly of fresh glasses associated with unaltered plagioclases and ferro-magnesian silicates (magnesio-hornblende and biotite). Glasses are of rhyolitic composition and, on the basis of the $\mathrm{K}_{2} \mathrm{O}$ vs. $\mathrm{SiO}_{2}$ plot, they lie in the field of calc-alkaline (Samples 124-767B-1H-6, 124-126 $\mathrm{cm}$; $-4 \mathrm{H}-6,41-43 \mathrm{~cm}$ ) or high-K calc-alkaline (Sample 124767B-6H-2, 90-92 cm) series (Peccerillo and Taylor, 1976) (Table 3; Fig. 2). Plagioclases are mainly andesine (37\%-51\% An) and labradorite (59\%-70\% An).

\section{Zone II "Glass Hydrolysis"}

Leaching zone (71.5-158 mbsf; Cores 124-767B-9H through $17 \mathrm{X}$ ). The characteristic of this zone is the coexistence of fresh and "altered" glasses in each individual ash layer. The composition of the fresh glasses ranges from andesites $\left(56 \%-63 \% \mathrm{SiO}_{2}\right)$ to rhyolites $\left(70 \%-76 \% \mathrm{SiO}_{2}\right)$ and belongs to the field of calc-alkaline (Sample 124-767B-9H-3, 61-63 cm) or high-K calc-alkaline series (Samples 124-767B10H-O6, 79-81 cm; -13X-CC, 5-7 cm). K-feldspar (49\%-66\% Or), plagioclases and ferro-magnesian minerals remain unaltered. Apart from typical dissolution features, altered glasses are chemically distinguished by their water content, a marked enrichment in alkalis, especially $\mathrm{K}$, and an increase of the $\mathrm{Al} / \mathrm{Si}$ ratio (Table 3 ; Fig. 2). Leaching affects both basic (andesitic) as well as acidic (rhyodacitic) glasses. The degree of alteration increases with depth, leading to the first authigenic mineral formation, i.e., smectite (iron beidellite type) and, secondarily, opal CT.

\section{Zone III "Phillipsite formation"}

Zeolite zone (158-329 mbsf; Cores 124-767B-18X through $-35 \mathrm{X})$. This zone is characterized by the crystallization of phillipsite. Feldspars (K-feldspars and plagioclases) and ferromagnesian minerals remain still unaltered. Association, or not, of zeolite with more or less "altered" glasses allows three subzones or levels to be distinguished.

An upper level (Zone IIIa) (158-233 mbsf; Cores 124-767B$18 \mathrm{X}$ through $-25 \mathrm{X})$, where fresh and "altered" andesitic glasses of high-K calc-alkaline series are mixed with grains showing phillipsite-smectite assemblages (Samples 124-767B$18 \mathrm{X}-4,29-31 \mathrm{~cm} ;-23 \mathrm{X}-1,54-56 \mathrm{~cm})$.

A medium narrow level (Zone IIIb) (233-329 msbf; Core 124-767B-26X), well defined by the complete replacement of glass by zeolite-smectite paragenesis.

A lower level (Zone IIIc) (242-329 msbf; Cores 124-767B$27 \mathrm{X}$ through $-35 \mathrm{X}$ ) Phillipsite is less abundant but there is more than in the upper level. Altered glasses reappear. Their 


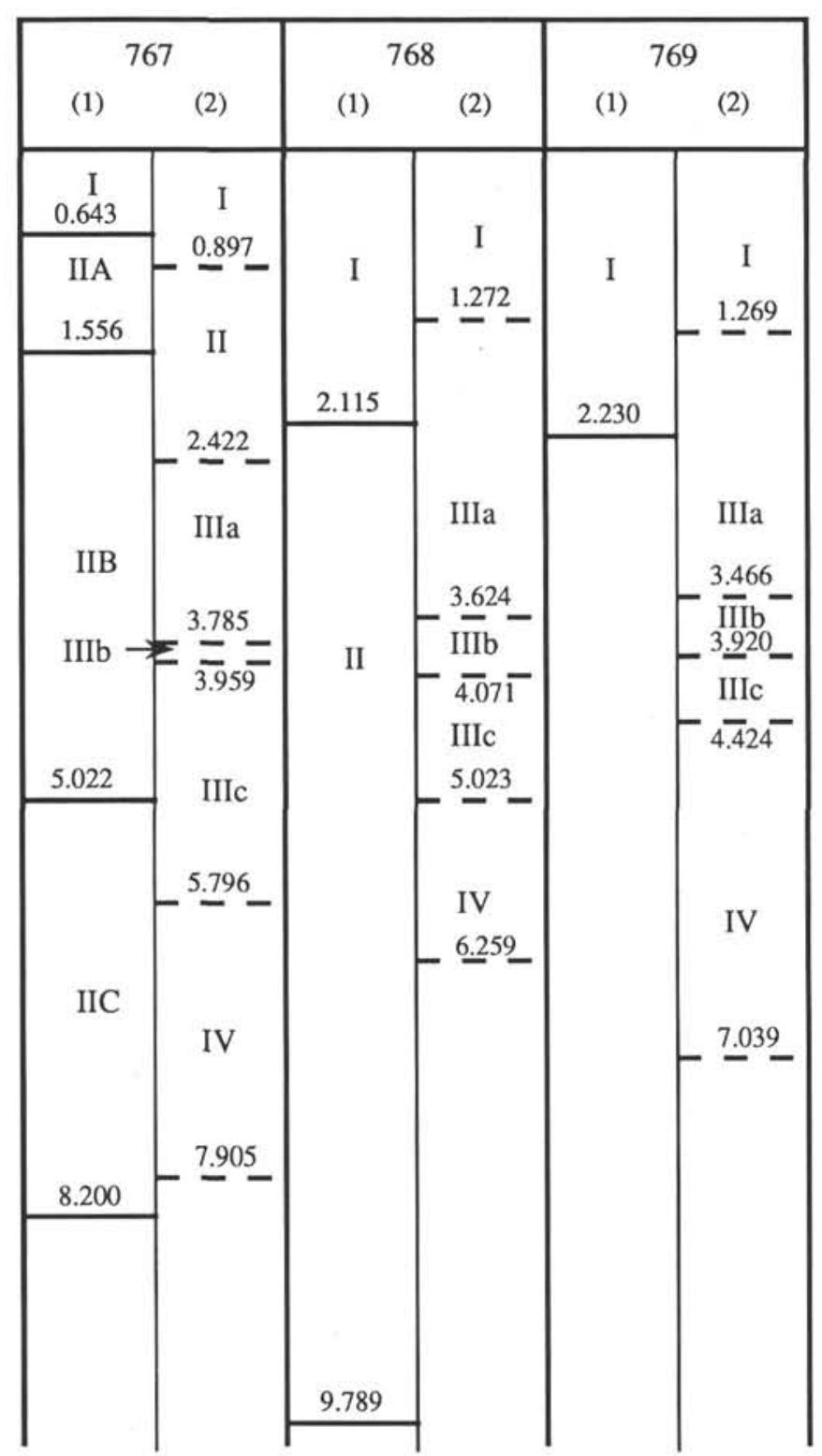

Figure 1. Relationship between lithostratigraphic Units (1) and diagenetic zones (2) for Sites 767, 768, and 769. Limits are given in Ma.

original chemical composition is difficult to define but seems in agreement with the alteration, as above, of both acidic and basic glasses.

\section{Zone IV "Smectite formation"}

Clayed zone ( 329 to $397 \mathrm{msbf}$; Cores 124-767B-36X through $-42 \mathrm{X})$. Ash layers in this zone are markedly bioturbated and reworked. Inherited minerals, quartz, and phyllosilicates are often mixed with volcanogenic material, leading to a high "Continentality Index" 6 (Rangin, Silver, von Breymann, et al., 1990). Phillipsite and altered glass are always present but in low amounts. The main characteristic of these ash layers is the massive growth of authigenic smectite (Samples 124-767B-

\footnotetext{
${ }^{6}$ Importance of continental sources, expressed by the logarithm of the sum of the abundances of smectite, illite, and chlorite, divided by the abundance of smectite.
}

$36 \mathrm{X}-2,114-116 \mathrm{~cm} ;-40 \mathrm{X}-1,7-9 \mathrm{~cm} ;-42 \mathrm{X}-06,22-24 \mathrm{~cm})$. The lower limit of this mixed zone is difficult to define. However, we presume that the sudden disappearance of hornblende and biotite below 410 mbsf could be correlated to the beginning of on-land volcanic explosive activity. This assumption is corroborated by the lack of any primary and secondary volcanogenic components at about $435 \mathrm{msbf}$ (Sample 124-767B-47X01, 54-56 cm).

\section{Sulu Sea (Site 768) and Cagayan Ridge (Site 769)}

The volcanic ashes of aeolian origin occur in two lithostratigraphic units (Fig. 1).

\section{Site 768}

Unit I (0-123 msbf; Cores 124-768B-1H to Section -768B$14 \mathrm{H}-3)$ is latest Pliocene to Holocene in age. It consists of interbedded marls and calcareous turbidites with sparse thin beds of volcanic ash.

Unit II (123-652 mbsf; Section 124-768B-14H-3 through Core 124-768C-31R) is middle Miocene to late Pliocene in age. It is composed mainly of alternating claystone, clayed siltstone, and siltstone with minor carbonate turbidites. Volcanic ashes occur in the upper part of this unit. A clear break appears at a depth of $260 \mathrm{msbf}$. The lack, of any volcanogenic component below this level, could signify, as noted in the Celebes Sea, the lower limit of the explosive volcanic activity.

\section{Site 769}

Unit I (0-102.15 mbsf; Cores 124-769A-1H through -769A$7 \mathrm{H}$; Core $124-769 \mathrm{~B}-1 \mathrm{H}$ through Section 124-769A-12 H-2) is late Pliocene to Holocene in age. The dominant lithology consists of nannofossil marl; volcanic ashes altered to clay become dominant at the base (Rangin, Silver, von Breymann, et al., 1990).

Unit II was divided into three subunits. Unit IIa (102.15262.35 msbf; Section 124-769B-12H-2 through Section $-29 \mathrm{X}-2$ ) is middle Miocene to late Pliocene in age. It is composed mainly of massive hemipelagic clay with abundant interlayered laminae representing deeply altered ash layers. No volcanogenic component of pyroclastic origin was observed below $185 \mathrm{mbsf}$, leading to the same interpretation as the one given for the Celebes Sea and for Site 768 discussed above.

The spatial distribution of previously defined diagenetic zones in the Celebes Sea is, as a whole, recognizable in the Sulu Sea and on the Cagayan Ridge (Table 2).

\section{Zone I "Fresh Glass"}

(Site 768: 0-89.5 mbsf, Cores 124-768B-1H through $-10 \mathrm{H}$. Site 769: 0-81.5 mbsf, Cores 124-769B-1H through $-9 \mathrm{H}$ ). Tephra consists mainly of fresh glasses associated with fresh alkali-feldspars, plagioclases and ferro-magnesian silicates. The chemical composition of glasses ranges from basaltic andesites $\left(52 \%-56 \% \mathrm{SiO}_{2}\right)$ and andesites $\left(56 \%-63 \% \mathrm{SiO}_{2}\right)$ to dacites $\left(63 \%-70 \% \mathrm{SiO}_{2}\right)$ and rhyolites $\left(70 \%-76 \% \mathrm{SiO}_{2}\right)$. On the basis of the $\mathrm{K}_{2} \mathrm{O}$ content, they belong, as in the Celebes Sea, either to the calc-alkaline series (Samples 124-768A-7H-4, 97-99 cm and $-769 \mathrm{~B}-7 \mathrm{H}-2,30-33 \mathrm{~cm})$ or to high-K calcalkaline series (Sample 124-768A-1H-5, 67-69 cm) (Fig. 2). Some samples are located at the limit of these two series (124-768B-4H-5, 14-16 cm and -768B-10H-5, 113-115 cm), Plagioclases are mainly andesines $(27 \%-57 \%$ An) and alkalifeldspars are K-rich feldspars $(66 \%-81 \%$ Or). Ferro-magnesian minerals consist of amphiboles (magnesio-hornblende), orthopyroxene $(70 \%-77 \% \mathrm{En})$ and biotite. 
Table 2. Location and age of diagenetic zones.

\begin{tabular}{|c|c|c|c|c|c|}
\hline ZONE & & & Site 767 & Site 768 & Site 769 \\
\hline \multirow[t]{3}{*}{ I } & Fresh glass & Core & $1 \mathrm{H}-8 \mathrm{H}$ & $1 \mathrm{H}-10 \mathrm{H}$ & $1 \mathrm{H}-9 \mathrm{H}$ \\
\hline & & Depth (mbsf) & $0-71.5$ & $0-89.5$ & $0-81.5$ \\
\hline & & Age (Ma) & $0-0.897$ & $0-1.272$ & $0-1.369$ \\
\hline \multirow[t]{3}{*}{ II } & Glass hydrolysis & Core & $9 \mathrm{H}-17 \mathrm{X}$ & & \\
\hline & & Depth (mbsf) & $71.5-158$ & & \\
\hline & & Age (Ma) & $0.897-2.422$ & & \\
\hline \multirow[t]{12}{*}{ III } & Phillipsite formation & Core & $18 \mathrm{X}-35 \mathrm{X}$ & $11 \mathrm{H}-21 \mathrm{H}$ & $10 \mathrm{H}-16 \mathrm{H}$ \\
\hline & & Depth (mbsf) & $158-329$ & $89.5-193$ & $81.5-148$ \\
\hline & & Age (Ma) & $2.422-5.796$ & $1.272-5.023$ & $1.369-4.424$ \\
\hline & III a & Core & $18 \mathrm{X}-25 \mathrm{X}$ & $11 \mathrm{H}-17 \mathrm{H}$ & $11 \mathrm{H}-14 \mathrm{H}$ \\
\hline & & Depth (mbsf) & $158-233$ & $89.5-156$ & $81.5-129$ \\
\hline & & Age (Ma) & $2.422-3.795$ & $1.272-3.624$ & $1.369-3.466$ \\
\hline & IIIb & Core & $26 X$ & $18 \mathrm{H}$ & $15 \mathrm{H}$ \\
\hline & & Depth (mbsf) & $233-242$ & $156-165$ & $129-138$ \\
\hline & & Age (Ma) & 3.795-3.959 & $3.624-4.071$ & $3.466-3.920$ \\
\hline & IIIc & Core & $27 X-35 X$ & $19 \mathrm{H}-21 \mathrm{H}$ & $16 \mathrm{H}$ \\
\hline & & Depth (mbsf) & 242-329 & $165-193$ & $138-148$ \\
\hline & & Age (Ma) & $3.959-5.796$ & $4.071-5.023$ & $3.920-4.424$ \\
\hline \multirow[t]{3}{*}{ IV } & Smectite formation & Core & $36 \mathrm{X}-42 \mathrm{X}$ & $22 \mathrm{H}-29 \mathrm{X}$ & $16 \mathrm{H}-21 \mathrm{H}$ \\
\hline & & Depth (mbsf) & $329-397$ & 193-258 & $148-185$ \\
\hline & & Age (Ma) & $5.796-7.905$ & $5.023-6.259$ & $4.424-7.039$ \\
\hline
\end{tabular}

\section{Zone II "Glass Hydrolysis"}

This zone, showing gradational evolution of alteration processes at Site 767, is apparently missing at Sites 768 and 769.

\section{Zone III "Phillipsite Formation"}

(Site 768: 89.5-193 msbf, Cores 124-768B-11H through -21H. Site 769: 81.5- 148 mbsf, Cores 124-769B-10H through $-16 \mathrm{H})$. The contact with the above zone is very sharp. Feldspars and ferro-magnesian minerals remain unaltered. Phillipsite is always associated with smectite and also with fresh and altered glass. The relative abundance of phillipsite permits us to distinguish three levels.

\section{Zone IIIa - Upper Level}

At the top, phillipsite coexists with fresh and altered glass (Site 768: 89.5 to 108 mbsf, Cores $124-768 \mathrm{~B}-11 \mathrm{H}$ through $12 \mathrm{H}$. Site 769 : 81.5 to 120 mbsf, Cores $124-769 \mathrm{~B}-10 \mathrm{H}$ through $-13 \mathrm{H}$ ) and subsequently only with altered glass (Site 768, 108-156 mbsf; Cores 124-768B-13H through $-17 \mathrm{H}$. Site 769: 120-129 mbsf; Core 124-769B-14H). Fresh glasses are of rhyolitic composition (Sample 124-768B-12H, 72-75 cm; high-K calc-alkaline series) and altered glasses are related to either acidic (rhyodacitic) or basic (andesitic) composition (Samples 124-768B$12 \mathrm{H}, 72-75 \mathrm{~cm}$; $-14 \mathrm{H}-02,132-134 \mathrm{~cm} ;-14 \mathrm{H}-03,98-100 \mathrm{~cm})$.

\section{Zone III - Medium Level}

Limited to Cores 124-768B-18H and -769B-15H (156 to 165 mbsf and 129 to 138 mbsf, respectively), this zone is nevertheless well characterized by a massive phillipsite-smectite assemblage with complete disappearance of vitric glasses (Samples 768B-12H-6, 52-53 cm and 53-54 cm; -769B-15H-2, 20-22 $\mathrm{cm}$ and $56-58 \mathrm{~cm})$.

\section{Zone IIIc - Lower Level}

(Site 768: 165-193 mbsf, Cores 124-768B-19H through -21 H. Site 769B: $138-148$ mbsf, Core 124-769B-16H). Altered glasses coexist again, as in level IIIa with authigenic minerals (Samples 124-768B-21H-2, 115-120 cm and -769B-16H-5, $50-52 \mathrm{~cm})$. However, there are no fresh glass subunits at this level.

\section{Zone IV "Smectite Formation"}

(Site 768: 193-258 mbsf; Cores 124-768B-22H through $29 \mathrm{X}$ ). This zone is marked by the abundance of smectite associated with a few amount of altered glass and phillipsite. In some cases, volcanogenic components, of primary and secondary origin, are more or less diluted by inherited material, as emphasized by a high "Continentality Index" (Rangin, Silver, von Breymann, et al., 1990). As mentioned before, we place the lack of pyroclastic material to the lower limit of this zone.

\section{CHEMICAL COMPOSITION OF ALTERATION PRODUCTS}

"Altered Glass"

Bulk analysis on an individual glass shard showing distinctive dissolution features was, compared to analysis of fresh glass, inferred as representative of the initial composition. The results indicate that the alteration is characterized by: (1) an increase of the $\mathrm{H}_{2} \mathrm{O}$ content; (2) a decrease of the $\mathrm{Si} / \mathrm{Al}$ ratio; (3) an increase of the content of Na and especially K (Fig. 2, Table 3). Punctual analyses with a SEM on the same "altered" glass shard reveal large heterogeneity and a scale of compositions from residual (?) glass and residual laths of 


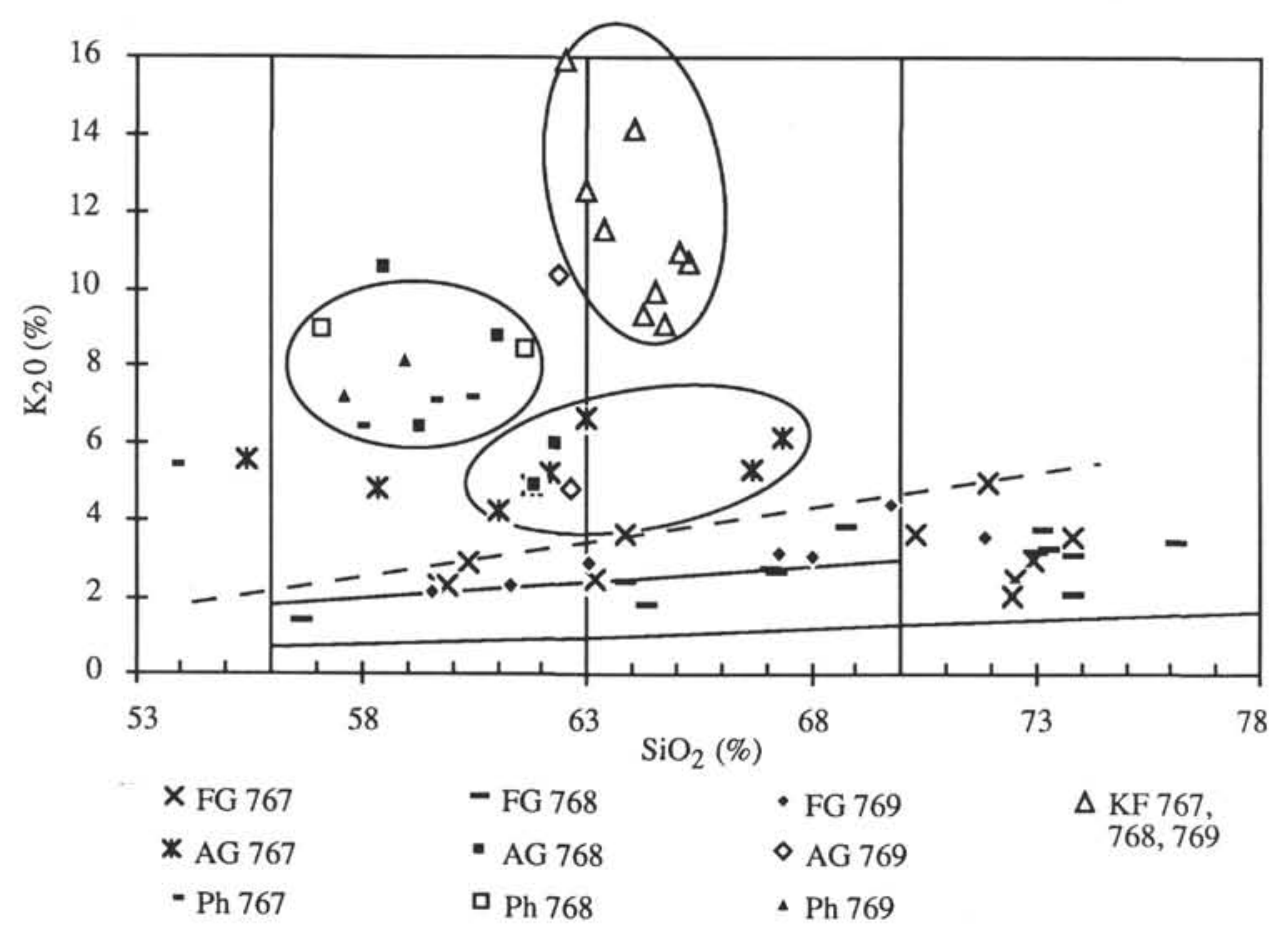

Figure $2 . \mathrm{K}_{2} \mathrm{O}$ vs. $\mathrm{SiO}_{2}$ variation diagram. Each symbol represents, for a given sample, the mean value of individual glass shards or mineral analyses (See Table 3). FG: fresh glass; AG: altered glass; Ph: phillipsite; KF: K-feldspar, from Sites 767, 768, and 769. Representative fields of "altered" glasses, K-feldspars and phillipsite, more-or-less associated with "altered" glasses, were plotted. Solid lines indicate boundaries of low-K calc-alkaline, calc-alkaline, high $\mathrm{K}$ calc-alkaline series after Peccerillo and Taylor (1976). Dashed line is the limit of fresh glasses analyzed.

$\mathrm{K}$-feldspars or plagioclases to intergrown zeolite and clay minerals. In another environmental context, this mixture, confirmed by XRD studies, would be noted as "palagonite", (Honnorez, 1981). All stages exist between fresh vitric glass, acidic or basic, "altered" glass, and pure phillipsite and/or smectite.

\section{Zeolites}

On SEM observations, glomerules composed of agglomerates of well-developed prismatic crystals of phillipsite are very common. Structural formulas deduced from punctual analyses on individual crystals, on the basis of 32 oxygens, range from

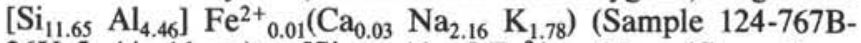
$26 \mathrm{X}-5,44-46 \mathrm{~cm})$ to $\left[\mathrm{Si}_{11.34} \mathrm{Al}_{4.80}\right] \mathrm{Fe}^{2+}{ }_{0.02} \mathrm{Mg}_{0.02}\left(\mathrm{Ca}_{0.12} \mathrm{Na}_{1.65}\right.$ $\mathrm{K}_{2.28}$ ) (Sample 124-768B-18H-6, 52-53 cm) (Table 3). Si/Al ratios ranging from 2.79 to 2.36 and a very low $\mathrm{Ca}$ content compared to alkalis $\mathrm{Na}$ and $\mathrm{K}$, are characteristics of pelagic phillipsite (Stonecipher, 1978). Mafic glasses and acidic glasses are often cited in deep-sea sediments as preferential parental precursors of phillipsite and clinoptilolite, respectively (Kastner and Stonecipher, 1978; Iijima, 1978). In our study, both basic andesitic and rhyolitic glasses are linked to phillipsite formation. Nevertheless, their chemical parental composition could be reflected in the $\mathrm{Si} / \mathrm{Al}$ and $\mathrm{Na} / \mathrm{K}$ variations (Fig. 3).

\section{Alkali-Feldspars}

Two types of K-feldspars can be distinguished. Some (49\% to $66 \%$ Or) are concentrated in the fraction $>63 \mu \mathrm{m}$ and, evidently, are of primary magmatic origin. Others, of more restricted composition ( $80 \%$ Or), and only found in association with phillipsite, are probably authigenic (Table 3 ). Nevertheless, they are relatively rare and sparse compared to zeolite, and any zonal distribution similar to the latter was obvious within the three studied sites.

\section{Clay Minerals}

Inherited minerals, illite, kaolinite, chlorite, and also smectite, can be mixed by bioturbation or reworking with authigenic smectite (Nicot et al., this volume). Detrital smectite is usually of aluminous composition (b parameter deduced from the (06.33) band on an XRD diagram, at about $9 \AA$ ). Authigenic smectite shows larger scale of 060 peaks, ranging from 1.496 to $1.518 \AA$ and reflecting various chemical compositions (Desprairies, 1983). Heterogeneity was confirmed by punctual analyses on SEM and leads us to consider each sample as a mixture of species ranging from aluminous beidellite to ironrich beidellite and even nontronite (Table 4). This heterogeneity could reflect successive stages of formation and dissolution-recrystallization connected to the increasing degree of alteration. Parental composition of the glass plays a prominent part in the chemical composition of the final product. Finally, a positive correlation appears between the $\mathrm{K}_{2} \mathrm{O}$ and iron content of the smectite (Table 4). Using the position of the combination peaks $(001)_{10} /(002)_{17}$ and $(002)_{10} /(003)_{17}$ on ethylene-glycol solvated samples (Reynolds and Hower, 1970), we found values of randomly interstratified illite/smectite with $80 \%$ to $100 \%$ of expandable layers.

\section{DISCUSSION}

\section{Correlation of Diagenetic Zones with the Lithostratigraphy}

Ages of the diagenetic zones defined above, based on distribution of ash layers, can be inferred from biostratigraphic zonations and sedimentation rates (Rangin, Silver, 
Table 3. Major-element analyses of fresh glasses (FG), altered glasses (AG), phillipsite (Ph), and K-feldspars (KF). For a given sample (Table 1), data represent mean of individual EM analyses (Sites 767 and 768) or individual SEM/EDS analyses (Site 769) recalculated to $95 \%-97 \%$ (glasses), 90\% (zeolites) $98 \%$ (K-feldspars). (See Methodology and Analytical Procedure section).

\begin{tabular}{|c|c|c|c|c|c|c|c|c|c|c|c|c|c|c|c|c|c|c|c|c|}
\hline \multirow{4}{*}{$\begin{array}{c}\text { Core, section } \\
\text { Interval }(\mathrm{cm}) \\
\text { Mean }\end{array}$} & \multicolumn{10}{|c|}{ SITE 767} & \multicolumn{10}{|c|}{ SITE 768} \\
\hline & 1H-6 & $4 \mathrm{H} \cdot 6$ & $6 \mathrm{H}-2$ & $9 \mathrm{H}-3$ & $9 \mathrm{H}-3$ & $10 \mathrm{H}-6$ & $13 \mathrm{X}-\mathrm{CC}$ & $13 \mathrm{X}-\mathrm{CC}$ & $18 X-4$ & $18 \times-4$ & $1 \mathrm{H}-\mathrm{S}$ & $4 \mathrm{H}-5$ & $4 \mathrm{H}-5$ & $4 \mathrm{H}-5$ & $7 \mathrm{H}-4$ & $7 \mathrm{H}-4$ & $7 \mathrm{H}-4$ & $10 \mathrm{H}-5$ & 10H-5 & $10 \mathrm{H}-5$ \\
\hline & $124-126$ & $41-43$ & $90-92$ & $61-63$ & $61-63$ & 79.81 & 5.7 & $5-7$ & 29.31 & 29.31 & 69.71 & 14.16 & $14-16$ & $14-16$ & $97-99$ & 97.99 & $97-99$ & 113.115 & $113-115$ & $113-115$ \\
\hline & $\mathrm{FG} / 10$ & $\mathrm{FG} / 12$ & $\mathrm{FG} / 6$ & $\mathrm{FG} / \mathrm{S}$ & $\mathrm{FG} / 3$ & $\mathrm{FG} / 4$ & $\mathrm{FG} / \mathrm{S}$ & $\mathrm{FG} / 3$ & $\mathrm{FG} / 3$ & $\mathrm{FG} / 8$ & $\mathrm{FG} / 7$ & $\mathrm{FG} / 10$ & $\mathrm{FG} / 2$ & $\mathrm{FG} / 14$ & $\mathrm{FG} / 2$ & $\mathrm{FG} / 2$ & $\mathrm{FG} / 7$ & $\mathrm{FG} / 2$ & $\mathrm{FG} / 2$ & FG/11 \\
\hline $\mathrm{SiO}_{2}$ & 72.91 & 72.56 & 71.93 & 72.47 & 60.35 & 73.85 & 70.30 & 59.71 & 63.86 & 59.91 & 73.17 & 73.26 & 67.24 & 73.82 & 73.84 & 64.30 & 56.65 & 76.10 & 67.12 & 63.89 \\
\hline $\mathrm{TiO}_{2}$ & 0.18 & 0.08 & 0.06 & 0.08 & 0.73 & 0.17 & 0.02 & 0.61 & 0.35 & 0.42 & 0.13 & 0.07 & 0.62 & 0.10 & 0.14 & 0.70 & 1.09 & 0.10 & 0.54 & 0.63 \\
\hline $\mathrm{Al}_{2} \mathrm{O}_{3}$ & 12.57 & 12.89 & 12.28 & 13.13 & 17.86 & 12.07 & 12.52 & 15.53 & 17.39 & 19.78 & 11.47 & 12.63 & 15.92 & 13.08 & 12.85 & 18.01 & 17.20 & 12.74 & 14.64 & 15.76 \\
\hline $\mathrm{FeO}$ & 1.01 & 0.96 & 0.88 & 0.85 & 4.48 & 0.92 & 1.07 & 5.26 & 3.66 & 3.90 & 0.87 & 0.65 & 2.43 & 0.89 & 0.71 & 4.07 & 8.49 & 0.58 & 2.14 & 3.17 \\
\hline $\mathrm{MnO}$ & 0.04 & 0.03 & 0.04 & 0.03 & 0.19 & 0.00 & 0.07 & 0.15 & 0.11 & 0.07 & 0.09 & 0.03 & 0.05 & 0.03 & 0.05 & 0.05 & 0.18 & 0.00 & 0.06 & 0.03 \\
\hline $\mathrm{MgO}$ & 0.21 & 0.22 & 0.03 & 0.24 & 0.76 & 0.09 & 0.14 & 1.17 & 0.54 & 0.57 & 0.10 & 0.12 & 0.42 & 0.32 & 0.19 & 1.18 & 3.33 & 0.08 & 0.68 & 1.23 \\
\hline $\mathrm{CaO}$ & 1.21 & 1.62 & 0.76 & 1.39 & 5.00 & 0.82 & 1.02 & 4.11 & 3.49 & 5.80 & 0.94 & 1.39 & 2.99 & 1.56 & 1.35 & 4.49 & 7.61 & 1.00 & 2.33 & 3.35 \\
\hline $\mathrm{N}:{ }_{2} \mathrm{O}$ & 3.73 & 3.60 & 3.12 & 3.13 & 4.67 & 3.47 & 3.65 & 4.71 & 5.82 & 4.96 & 3.58 & 3.94 & 5.42 & 3.38 & 3.79 & 5.91 & 3.56 & 3.92 & 4.55 & 4.81 \\
\hline $\mathrm{K}_{2} \mathrm{O}$ & 2.95 & 2.47 & 5.00 & 2.08 & 294 & 3.61 & 3.62 & 2.32 & 3.62 & 2.32 & 3.76 & 3.27 & 2.65 & 3.08 & 2.02 & 1.82 & 1.37 & 3.37 & 2.70 & 2.40 \\
\hline$\Sigma$ & 94.80 & 94.42 & 94.09 & 93.41 & 96.98 & 94.99 & 92.42 & 93.57 & 98.85 & 97.75 & 94.11 & 95.35 & 97.73 & 96.27 & 94.92 & 100.50 & 99.48 & 97.86 & 94.74 & 95.26 \\
\hline Core, section & $23 x-1$ & & $9 \mathrm{H}-3$ & $10 \mathrm{H} \cdot 6$ & $13 \mathrm{X}-\mathrm{CC}$ & $18 X-4$ & $23 x-1$ & $26 \times-5$ & $29 \times-2$ & $40 \mathrm{X}-1$ & $12 \mathrm{H}-5$ & $12 \mathrm{H}-5$ & & $12 \mathrm{H}-5$ & $12 \mathrm{H}-5$ & $14 \mathrm{H}-2$ & $14 \mathrm{H}-3$ & $21 \mathrm{H}-2$ & & \\
\hline Interval (cm) & 54.56 & & $61-63$ & 79.81 & 5.7 & $29-31$ & $54-56$ & $44-46$ & $117-119$ & 7.9 & 72.75 & 72.75 & & 72.75 & 72.75 & $132-134$ & $98-100$ & $115-120$ & & \\
\hline Mean & $\mathrm{FG} / 4$ & & $A G / 6$ & $\mathrm{AG} / 3$ & $A G / 3$ & $\mathrm{AG/4}$ & $\mathrm{AG} / 2$ & $A G / 1$ & $A G / 3$ & $\mathrm{AG} / 2$ & $\mathrm{FG} / \mathrm{S}$ & $\mathrm{FG} / 2$ & & $\mathrm{AG} / 3$ & $A G / 3$ & $\mathrm{AG} / 8$ & $\mathrm{AG} / 2$ & $\mathrm{AG} / 4$ & & \\
\hline $\mathrm{SiO}_{2}$ & 63.16 & & 67.34 & 62.16 & 55.43 & 61.79 & 61.06 & 58.32 & 62.99 & 66.66 & 73.03 & 68.78 & & 62.33 & 61.00 & 61.86 & 58.45 & 59.28 & & \\
\hline $\mathrm{TiO}_{2}$ & $\begin{array}{r}1.63 \\
1.63\end{array}$ & & $\begin{array}{r}0.94 \\
0.25\end{array}$ & $\begin{array}{r}62.16 \\
0.56\end{array}$ & $\begin{array}{r}3.43 \\
0.56\end{array}$ & $\begin{array}{r}1.79 \\
0.28\end{array}$ & $\begin{array}{r}1.06 \\
0.09\end{array}$ & $\begin{array}{r}8.32 \\
0.17\end{array}$ & $\begin{array}{r}2.999 \\
0.02\end{array}$ & $\begin{array}{r}60.00 \\
0.01\end{array}$ & $\begin{array}{l}3.03 \\
0.27\end{array}$ & $\begin{array}{r}0.78 \\
0.38\end{array}$ & & $\begin{array}{r}0.00 \\
0.00\end{array}$ & 0.04 & $\begin{array}{r}1.80 \\
0.13\end{array}$ & 0.14 & $\begin{array}{r}0.00 \\
0.00\end{array}$ & & \\
\hline $\mathrm{Al}_{2} \mathrm{O}_{3}$ & 15.37 & & 15.63 & 18.46 & 17.14 & 16.99 & 22.32 & 22.04 & 20.03 & 13.74 & 12.49 & 12.62 & & 16.17 & 20.84 & 18.73 & 18.66 & 19.93 & & \\
\hline $\mathrm{FeO}$ & 5.39 & & 1.65 & 283 & 5.13 & 3.29 & 0.83 & 0.40 & 0.60 & 0.10 & 1.07 & 1.36 & & 0.11 & 0.88 & 1.42 & 0.63 & 0.79 & & \\
\hline $\mathrm{MnO}$ & 0.10 & & 0.13 & 0.11 & 0.07 & 0.15 & 0.00 & 0.00 & 0.00 & 0.00 & 0.03 & 0.00 & & 0.00 & 0.01 & 0.05 & 0.09 & 0.00 & & \\
\hline $\mathrm{MgO}$ & 1.51 & & 0.35 & 0.64 & 1.16 & 0.79 & 0.23 & 0.07 & 0.00 & 0.15 & 0.19 & 0.26 & & 0.49 & 0.62 & 0.75 & 0.00 & 0.01 & & \\
\hline $\mathrm{CaO}$ & 3.87 & & 1.46 & 3.09 & 4.74 & 2.59 & 5.17 & 2.20 & 2.41 & 2.31 & 1.10 & 0.93 & & 1.82 & 2.68 & 2.62 & 1.16 & 2.63 & & \\
\hline $\mathrm{Na}_{2} \mathrm{O}$ & 4.32 & & 3.40 & 5.15 & 3.92 & 4.63 & 5.21 & 5.78 & 5.11 & 1.33 & 3.81 & 3.66 & & 1.31 & 2.48 & 4.23 & 2.72 & 4.74 & & \\
\hline $\mathrm{K}_{2} \mathrm{O}$ & 2.47 & & 6.22 & 5.23 & 5.55 & 4.89 & 4.26 & 4.83 & 6.71 & 5.31 & 3.16 & 3.83 & & 6.02 & 8.81 & 4.91 & 10.55 & 6.46 & & \\
\hline$\Sigma$ & 97.80 & & 96.42 & 98.23 & 93.71 & 95.38 & 99.15 & 93.81 & 97.86 & 89.61 & 95.15 & 91.80 & & 88.25 & 97.36 & 94.69 & 92.37 & 93.83 & & \\
\hline Core, section & $26 \mathrm{X}-5$ & $29 \mathrm{X}-2$ & $29 X-2$ & $35 X-5$ & & $10 \mathrm{H}-6$ & $29 \mathrm{X}-2$ & $35 X-5$ & $40 X-1$ & $40 \mathrm{X}-1$ & $14 \mathrm{H}-3$ & $18 \mathrm{H}-6$ & & $12 \mathrm{H}-5$ & $18 \mathrm{H}-6$ & & & & & \\
\hline Interval (cm) & $44-46$ & $117-119$ & $117-119$ & $8-10$ & & 79.81 & $117-119$ & 8-10 & $7-9$ & 7.9 & $98-100$ & 52.54 & & $72-75$ & $52-54$ & & & & & \\
\hline Mean & $\mathrm{Ph} / 8$ & $\mathrm{P} / \sqrt{2}$ & $\mathrm{P} h / 1$ & $\mathrm{Ph} / 3$ & & $\mathrm{KF} / \mathrm{I}$ & $\mathrm{KF} / \mathrm{B}$ & $\mathrm{KF} / 1$ & $\mathrm{KF} / 4$ & $\mathrm{KF} / 2$ & $\mathrm{Ph} / 2$ & Pt/11 & & $\mathrm{KF} / 7$ & $\mathrm{KF} / 2$ & & & & & \\
\hline $\mathrm{SiO}_{2}$ & 59.58 & 53.86 & 60.33 & 57.94 & & 65.30 & 64.25 & 64.70 & 64.56 & 64.07 & 61.63 & 57.13 & & 62.98 & 63.37 & & & & & \\
\hline $\mathrm{TiO}_{2}$ & 0.04 & 0.14 & 0.00 & 0.00 & & 0.02 & 0.02 & 0.19 & 0.03 & 0.00 & 0.09 & 0.04 & & 0.00 & 0.00 & & & & & \\
\hline $\mathrm{Al}_{2} \mathrm{O}_{3}$ & 19.36 & 18.34 & 18.37 & 19.15 & & 18.54 & 18.45 & 19.43 & 19.35 & 17.84 & 19.00 & 20.54 & & 18.25 & 18.89 & & & & & \\
\hline $\mathrm{F}=\mathrm{O}$ & 0.08 & 0.46 & 0.00 & 0.09 & & 0.21 & 0.15 & 0.46 & 0.21 & 0.03 & 0.71 & 0.14 & & 0.67 & 0.11 & & & & & \\
\hline $\mathrm{MnO}$ & 0.04 & 0.07 & 0.00 & 0.05 & & 0.00 & 0.04 & 0.00 & 0.02 & 0.08 & 0.02 & 0.00 & & 0.00 & 0.00 & & & & & \\
\hline $\mathrm{MgO}$ & 0.00 & 0.24 & 0.00 & 0.00 & & 0.00 & 0.02 & 0.05 & 0.01 & 0.07 & 0.04 & 0.05 & & 0.22 & 0.00 & & & & & \\
\hline $\mathrm{CaO}$ & 0.15 & 0.64 & 0.07 & 0.35 & & 0.36 & 0.70 & 1.84 & 0.64 & 0.06 & 1.65 & 0.55 & & 0.68 & 0.43 & & & & & \\
\hline $\mathrm{Na}_{2} \mathrm{O}$ & 5.70 & 5.27 & 4.75 & 5.80 & & 3.46 & 4.37 & 3.53 & 3.86 & 0.94 & 4.00 & 4.28 & & 1.60 & 2.92 & & & & & \\
\hline $\mathrm{K}_{2} \mathrm{O}$ & 7.14 & 5.43 & 7.22 & 6.44 & & 10.71 & 9.42 & 9.10 & 9.96 & 14.20 & 8.47 & 8.99 & & 12.55 & 11.58 & & & & & \\
\hline$\Sigma$ & 92.09 & 84.42 & 90.74 & 89.81 & & 98.60 & 97.44 & 99.30 & 98.63 & 97.28 & 95.59 & 91.73 & & 96.95 & 97.28 & & & & & \\
\hline
\end{tabular}

von Breymann, et al., 1990). At each site, the zone boundaries are obviously independent of lithostratigraphic units (Fig. 1). The main diagenetic "event", i.e., the complete replacement of glass by a smectite-phillipsite assemblage, occurs between 3.5 and $4 \mathrm{Ma}$ both in the Celebes and Sulu Seas: between 3.8 and 3.96 Ma at Site 767, 3.62 and 4.07 Ma at Site 768, 3.47 and 3.92 Ma at Site 769. This "event" is located within the lithostratigraphic Unit II (Subunit IIB at Site 767) in which lithofacies are very uniform and not linked to noticeable changes in sedimentation rate $(50 \mathrm{~m} / \mathrm{m}$.y. at Site $767 ; 20$ $\mathrm{m} / \mathrm{m}$.y. at Sites 768 and 769).

However, the sharp boundary at Sites 768 and 769 of Zone I ("fresh glass") and Zone IIIa ("phillipsite formation") coincides with the rapid decrease in carbonate content consistent with the observed calcareous oozes (Rangin, Silver, von Breymann, et al., 1990). At site 767, the distribution of carbonate content is more sporadic and mostly linked to graded carbonate turbidites. The appearance at this site of the diagenetic "Transition Zone"' II ("glass hydrolysis") could reflect the origin and distribution of carbonate content within the three sites.

\section{Correlation of Diagenetic Zones with Volcanic Activity}

The variation of secondary volcanogenic products can be compared with that of primary volcaniclastic material observed on shipboard smear slides, specifically the presence of vitric glasses vs. crystals and lithic fragments and the frequency of ash layers (number or thickness of layers vs. time).

Zone I records a maximum in the on-land volcanic activity in the Pleistocene $(0-0.90 \mathrm{Ma}$ at Site $767 ; 0-1.27$ and $0-1.37$ at Sites 768 and 769 respectively).

Zones II and IIIa show the progress of alteration processes (increase in the percentage of crystals relative to fresh glass). However, enhanced alteration is concurrent with a decrease in the signal of explosive volcanism. This period extends up to about $3.5 \mathrm{Ma}$ on the upper part of Pliocene time (3.80 at Site $767 ; 3.62$ and 3.47 at Sites 768 and 769 , respectively).

Zone IIIb, related to a maximum in zeolitization process between 3.5 and $4 \mathrm{Ma}$, reveals a gap in the volcanic activity.

Zone IIIc is the recrudescence of explosive volcanism starting at different times: about $4.4 \mathrm{Ma}$ at Site $769,5 \mathrm{Ma}$ at Site 768, 5.8 Ma at Site 767. The characteristics are the same as in Zone IIIa, i.e., an opposite correlation between expressions of alteration and volcanism.

Zone IV is the period of mixed epiclastic-pyroclastic volcanism beginning at about $6.8 \mathrm{Ma}$. The paleoenvironmental signal of alteration seems completely different from that registered in the above zones.

Finally, the diagenetic zonation coincides with the volcanic cyclicity. Nevertheless, we emphasize that, sometimes, a deep alteration process can prevent any precise estimation of primary volcaniclastic material and thus its associated volcanic activity. 
Table 3 (continued).

\begin{tabular}{|c|c|c|c|c|c|c|c|c|}
\hline \multicolumn{9}{|c|}{ SITE 769} \\
\hline $7 \mathrm{H} \cdot 2$ & $7 \mathrm{H}-2$ & $9 \mathrm{H}-4$ & $9 \mathrm{H} \cdot 4$ & $9 \mathrm{H}-4$ & $14 \mathrm{H}-4$ & $14 \mathrm{H}-4$ & $14 \mathrm{H}-4$ & $16 \mathrm{H}-5$ \\
\hline $30-32$ & 30-32 & $126-128$ & $126-128$ & $126-128$ & $122-124$ & 122.124 & 122.124 & $50-52$ \\
\hline $\mathrm{FG} / 2$ & $\mathrm{FG} / 4$ & $\mathrm{FG} / 3$ & $\mathrm{FG} / 11$ & $\mathrm{FG} / 4$ & $\mathrm{FG} / 2$ & $\mathrm{FG} / 1$ & $\mathrm{AG} / 1$ & $\mathrm{AG} / 2$ \\
\hline 71.86 & 59.53 & 69.76 & 67.27 & 63.03 & 68.05 & 61.31 & 62.36 & 62.62 \\
\hline 0.31 & 1.00 & 0.54 & 0.77 & 1.04 & 0.51 & 0.00 & 0.00 & 0.33 \\
\hline 11.97 & 15.37 & 13.67 & 15.59 & 16.67 & 15.15 & 20.60 & 17.61 & 18.62 \\
\hline 1.14 & 5.51 & 1.59 & 2.68 & 3.26 & 2.38 & 0.46 & 0.47 & 0.83 \\
\hline 0.00 & 0.00 & 0.00 & 0.00 & 0.00 & 0.00 & 0.00 & 0.00 & 0.00 \\
\hline 0.27 & 2.83 & 0.23 & 0.85 & 1.57 & 1.03 & 0.00 & 0.00 & 0.59 \\
\hline 2.15 & 5.66 & 1.18 & 2.90 & 3.50 & 2.18 & 4.22 & 1.67 & 1.98 \\
\hline 3.74 & 4.95 & 3.63 & 3.79 & 5.03 & 4.60 & 8.12 & 4.48 & 7.23 \\
\hline 3.57 & 2.16 & 4.40 & 3.16 & 2.90 & 3.10 & 2.29 & 10.42 & 4.80 \\
\hline 95.00 & 97.00 & 95.00 & 97.00 & 97.00 & 97.00 & 97.00 & 97.00 & 97.00 \\
\hline $15 \mathrm{H}-2$ & $16 \mathrm{H}-5$ & $16 \mathrm{H}-5$ & & $15 \mathrm{H}-2$ & $15 \mathrm{H}-2$ & & & \\
\hline $56-58$ & $50-52$ & sa-52 & & $20-22$ & $20-22$ & & & \\
\hline $\mathrm{Ph} / 11$ & $\mathrm{Ph} / 1$ & $\mathrm{Ph} / 1$ & & $\mathrm{KF} / 1$ & $\mathrm{KF} / 1$ & & & \\
\hline 59.26 & 57.62 & 58.96 & & 65.06 & 62.48 & & & \\
\hline 0.00 & 0.27 & 0.30 & & 0.00 & 0.26 & & & \\
\hline 18.43 & 17.74 & 15.39 & & 17.49 & 18.12 & & & \\
\hline 0.14 & 0.79 & 1.14 & & 0.46 & 0.53 & & & \\
\hline 0.00 & 0.00 & 0.00 & & 0.00 & 0.00 & & & . \\
\hline 0.00 & 0.62 & 1.24 & & 0.00 & 0.00 & & & \\
\hline 1.54 & 0.57 & 0.56 & & 0.83 & 0.00 & & & \\
\hline 3.68 & 5.13 & 4.24 & & 3.17 & 0.67 & & & \\
\hline 6.95 & 7.26 & 8.17 & & 10.98 & 15.94 & & & \\
\hline 90.00 & 90.00 & 90.00 & & 98.00 & 98.00 & & & \\
\hline
\end{tabular}

\section{Correlation of Diagenetic Zones with Interstitial Water Concentration Gradients}

Interstitial water analyses from Sites 767,768 , and 769 show marked changes in concentration depth profiles of the dissolved constituents and their carbon, oxygen, and strontium isotopes (Rangin, Silver, von Breymann, et al., 1990; von Breymann, et al., this volume). Through the diagenetic zones, concentration gradients are as follows.

1. Dissolved silica values, below initial diffusion profile near the surface, remain virtually constant in Zone I and increase markedly in Zone II. A drastic change takes place in Zone IIIa: a strong depletion, which occurs faster at Sites 768 and 769 than at Site 767 and leads to minimum concentrations in Zone IIIc. Values remain low and unchanged in Zones IIIb and IV (Fig. 4).

2. Dissolved strontium shows concentration profiles comparable to that of dissolved silica (Fig. 5). Alkalinity and dissolved potassium values drop gradually within Zones II and IIIa of Site 767. An identical downward curvature, less demonstrative, is observed at Site 769. A similar trend exists at Site 768 for Zones I and IIIa, but alkalinity increases below this zone. Change in $\mathrm{pH}$ gradient is inversely correlated to the alkalinity (Fig. 5), remaining nearly constant from Zones I to IIIa and then increasing downward.

3. "The concentration depth profiles of calcium and magnesium are nonlinearly correlated throughout the sediment column"' (von Breymann, et al., this volume). Opposite trends with calcium enrichment and magnesium depletion, occur within Zone III. At Site 767, the intersection of curves coincides exactly with the beginning Zone IIIb (Fig. 6).

4. The oxygen and strontium isotopic composition of the pore fluids change gradually with depth (von Breymann, et al., this volume). The $\delta^{18} \mathrm{O}$ values decrease from $0 \%$ SMOW to approximately $-2 \%$ in Zone IIIb and those of ${ }^{87} \mathrm{Sr} /{ }^{86} \mathrm{Sr}$ from 0.709 to 0.707 .

The diagenetic reactions corresponding to the observed concentration gradients can be identified:

1. Zone I (Site 767). The increase in the dissolved silica and strontium concentrations and the decrease in dissolved potassium and alkalinity can be linked to the first stage of diagenetic reaction. Superimposed on the effect of glasses alteration, the addition of strontium to the pore fluids can be attributed to the recrystallization of biogenic calcite to inorganic calcite and aragonite (von Breymann, et al., this volume).

2. Zones IIIa and IIIb (Sites 767, 768, and 769). The observed $\delta^{18} \mathrm{O}$ depletion in the pore fluids, and isotopic values of dissolved strontium, support an explanation of exchange between volcanic ash material and interstitial water (von Breymann, et al., this volume).

Gradual depletion of alkalinity, dissolved silica, potassium, strontium, and magnesium reflects progressive alteration and replacement of glass by a dominant phillipsite-smectite assemblage sometimes associated with minor $\mathrm{K}$-feldspar and opal-CT or quartz. Calcium is easily released from glass; phillipsite and smectite are sinks for $\mathrm{K}$ and $\mathrm{Mg}$ (Kastner, 1976; Kastner and Gieskes, 1976; Gieskes and Lawrence, 1981). Uptake of $\mathrm{K}$ can be proved by bulk and fraction $>35 \mu \mathrm{m}$ chemical analyses of fresh and altered ash samples (Fig. 7). $\mathrm{Al} / \mathrm{Fe}$ ratio remains unchanged through the diagenetic zones, reflecting only the primordial chemical variations through the ash layers distribution and emphasizing that reactions were isochemical and conservative for these two elements. In contrast, $\mathrm{Al} / \mathrm{K}$ ratio decreases abruptly, reaching minimum value in Zone IIIb, and obviously is linked to the uptake of $\mathrm{K}$ by authigenic minerals, mainly phillipsite but also smectite having interstratification with illite layers. Finally, smectite is magnesium-poor and the consumption of magnesium is mainly related to dolomitization reactions (von Breymann, et al., this volume).

3. In Zones IIIc and IV, alkalinity, silica, and magnesium concentrations show low values and steady state. Glasses are completely altered to smectites, without zeolites. This alteration process is very common in open marine environments (Honnorez, 1981) and contrasts with the "zeolite facies" usually developed in more restricted environmental conditions (Rivière, 1989).

\section{Correlation of Diagenetic Zones with a Paleogeothermal Gradient}

To evaluate paleotemperatures of authigenic minerals formation, we performed isotopic analyses on smectite, phillipsite, and some associated components (glass, detrital smectite) (Table 5). Isotope ratio on three samples of authigenic smectite is about $26 \%$. Downhole distributions of $\delta^{18} \mathrm{O}$ of the pore water at Sites 767 and 768 show values of approximately $-2 \%$ in diagenetic Zone IIIb (von Breymann, et al., this volume).

Using a smectite-water isotopic fractionation factor of 1.03083 at $1^{\circ} \mathrm{C}$ (Yeh and Savin, 1976) the calculated paleotemperature is about $12^{\circ} \mathrm{C}$. Isotope ratio of phillipsite is about $24.5 \%$. Using a fractionation factor of 1.034 (Savin and Epstein, 1970a, b), the estimated paleotemperature is about the same. Therefore, isotopic data rule out any 


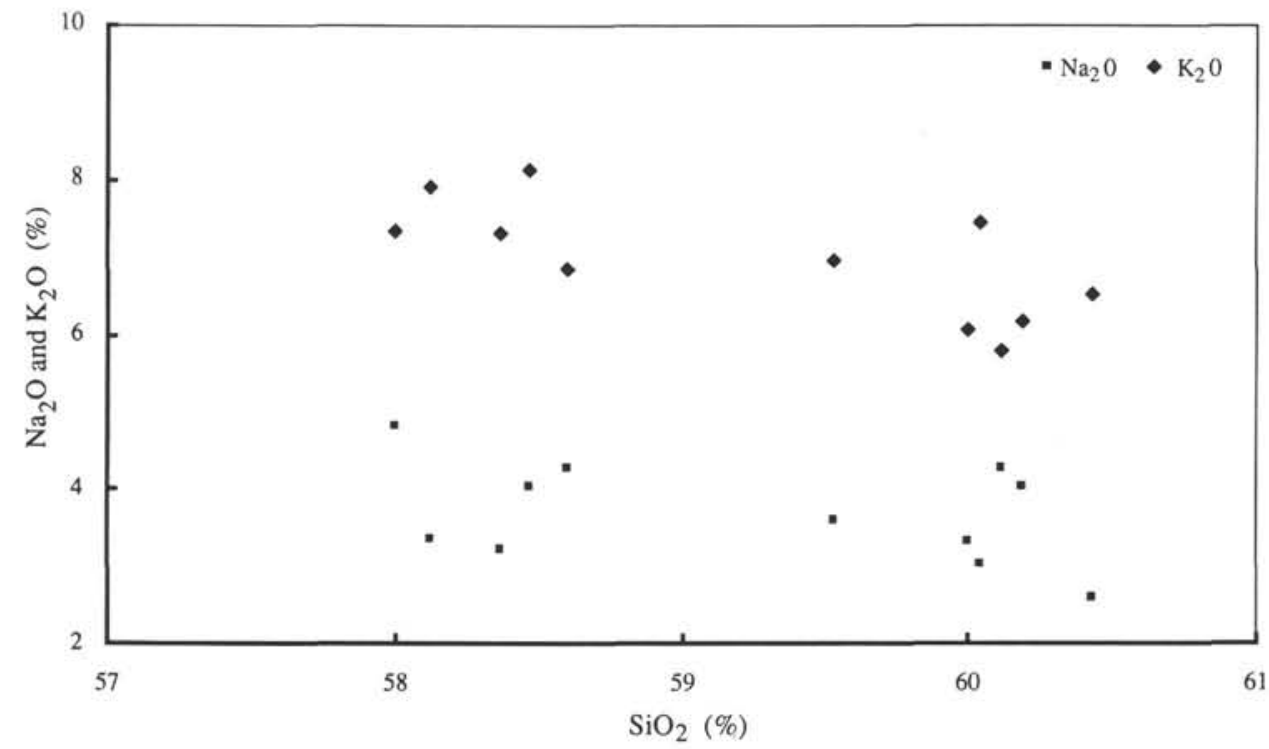

Figure 3. Example of oxide variations in phillipsite within a single ash layer (Sample 124-769B-15H-2, $56-58 \mathrm{~cm})$.

possibility of formation of either mineral under high-temperature gradients.

\section{SUMMARY AND CONCLUSIONS}

1. On the basis of mineralogical and chemical analyses performed on primary and secondary volcanic products, we have shown a zonal distribution of diagenesis through the Neogene tephra from the Celebes and Sulu Seas.

2. The largest of diagenetic alteration is observed in ash layers dated 3.5 to $4 \mathrm{Ma}$. No specific sedimentary environment is particular to this period except for the fact that it is related to a gap in on-land volcanism. Nevertheless, the alteration processes can partly obliterate signals of volcanic activity, i.e., frequency of ash layers.

3. This diagenetic "event" is synchronous in both basins. If the alteration is contemporaneous with sedimentation, this "event" corresponds to a change in the geodynamics of the basins at $4 \mathrm{Ma}$, when subduction of the Awe Sea northward to Mindanao Island ceased. It is relayed by incipient subduction along the Cotabato trench and renewal of activity along the Sulu trench (Pubellier et al., this volume).

4. Isotopic data imply low-temperature formation for authigenic smectite and phillipsite. Sites of diagenetic reactions are well correlated with interstitial water concentration gradients, suggesting time, as kinetic variable, and lithology as the main factors controlling the secondary mineralogy in a semiclosed model system.

\section{ACKNOWLEDGMENTS}

The authors express their sincere thanks to J. C. Alt and J. M. Gieskes for the critical review of manuscript. We gratefully acknowledge help and guidance from M. T. von Breymann and ODP Staff members. We would like thank Ph. Pradel for providing oxygen isotopic analyses. This study was supported by ASP-ODP France.

\section{REFERENCES}

Clayton, R. N., and Mayeda, T. K., 1963. The use of bromine pentafluoride in the extraction of oxygen from oxides and silicates for isotopic analyses. Geochim. Cosmochim. Acta, 27:43-52.
Desprairies, A., 1983. Relation entre le paramètre b des smectites et leur contenu en fer et magnésium. Application à l'étude des sédiments. Clays Clay Miner., 18:165-175.

Gieskes, J. M., and Lawrence, J. R., 1981. Alteration of volcanic matter in deep-sea sediments: evidence from the chemical composition of interstitial waters from deep-sea drilling cores. Geochim. Cosmochim. Acta, 45:1687-1703.

Honnorez, J., 1981. The aging of the oceanic crust at low temperature. In Emiliani, C. (Ed.), The Sea (Vol. 7): New York (Wiley), 525-587.

Iijima, A., 1978. Geological occurences of zeolite in marine environments. In Sand, L. B., and Mumpton, F. A. (Ed.), Natural Zeolites: Occurrence Properties Use: Oxford (Pergamon Press), 175-198.

Kastner, M., 1976. Diagenesis of basal sediments and basalts of Site 322 and 323, Leg 35, Bellingshausen Abyssal Plain. In Hollister C. D., Craddock, C., et al., Init. Repts. DSDP, 35: Washington (U.S. Govt. Printing Office), 513-527.

Kastner, M., and Gieskes, J. M., 1976. Interstitial water profiles and sites of diagenetic reactions, Leg 35, DSDP, Bellingshausen Abyssal Plain. Earth Planet. Sci. Lett., 33:11-20.

Kastner, M., and Stonecipher, S. A., 1978. Zeolites in pelagic sediments of the Atlantic, Pacific, and Indian oceans. In Sand, L. B., and Mumpton, F. A. (Eds.), Natural Zeolites: Occurrence, Properties, Use: New York (Pergamon Press), 199218.

Peccerillo, A., and Taylor, S. R., 1976. Geochemistry of Eocene calc-alkaline volcanic rocks from the Kastamonu area, northern Turkey. Contrib. Mineral. Petrol., 58:63-81.

Rangin, C., 1989. The Sulu Sea, a back arc basin setting within a Neogene collision zone. Tectonophysics, 161:119-141.

Rangin, C., Silver, E. A., von Breymann, M. T., et al., 1990. Proc. ODP, Init. Repts., 124: College Station, TX (Ocean Drilling Program).

Reynolds, R. C., and Hower, J., 1970. The nature of interlayering in mixed-layer illite-montmorillonites. Clays Clay Miner., 18:2536.

Rivière, M., 1989. En avant et en arrière du bloc d'Alboran, les paragenèses diagénétiques à zéolites des dépôts volcanogéniques marins témoignent d'un épisode de confinement burdigalien. $C$. $R$. Acad. Sci. Ser. 2, 309:1407-1412.

Savin, S. M., and Epstein, S., 1970a. The oxygen and hydrogen isotope geochemistry of clay minerals. Geochim. Cosmochim. Acta, 34:25-42. 
Savin, S. M., and Epstein, S., 1970b. The oxygen and hydrogen isotope geochemistry of ocean sediments and shales. Geochim. Cosmochim. Acta, 34:43-63.

Stonecipher, S. A., 1978. Chemistry of deep-sea phillipsite clinoptilolite, and host sediments. In Sand, L. B., and Mumpton, F. A. (Eds.), Natural Zeolite: Occurrence, Properties, Use: New York (Pergamon Press), 221-234.
Yeh, H. W., Savin, S. M., 1976. The extent of oxygen isotope exchange between clay minerals and sea water. Geochim. Cosmochim. Acta, 40:743-748.

Date of initial receipt: 25 June 1990 Date of acceptance: 9 January 1991 Ms 124B-178 
Table 4. Chemical analyses, and structural formulas on the basis of 11 oxygens, and b-parameter for smectite from altered ash layers, Site 767 . Clay fraction ( $2 \mu \mathrm{m}$ ) or mean values of individual analyses (No) are normalized to 100 .

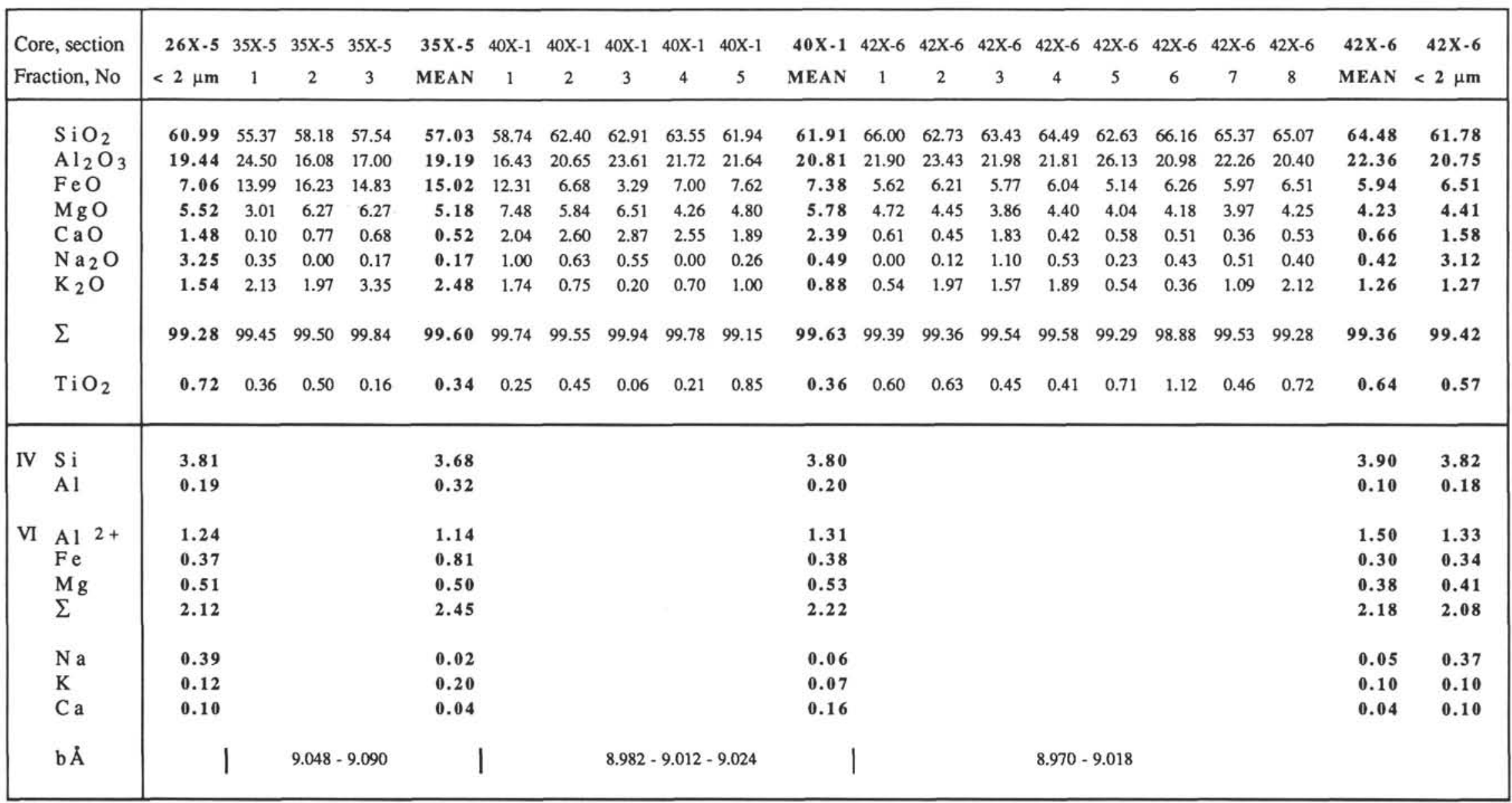




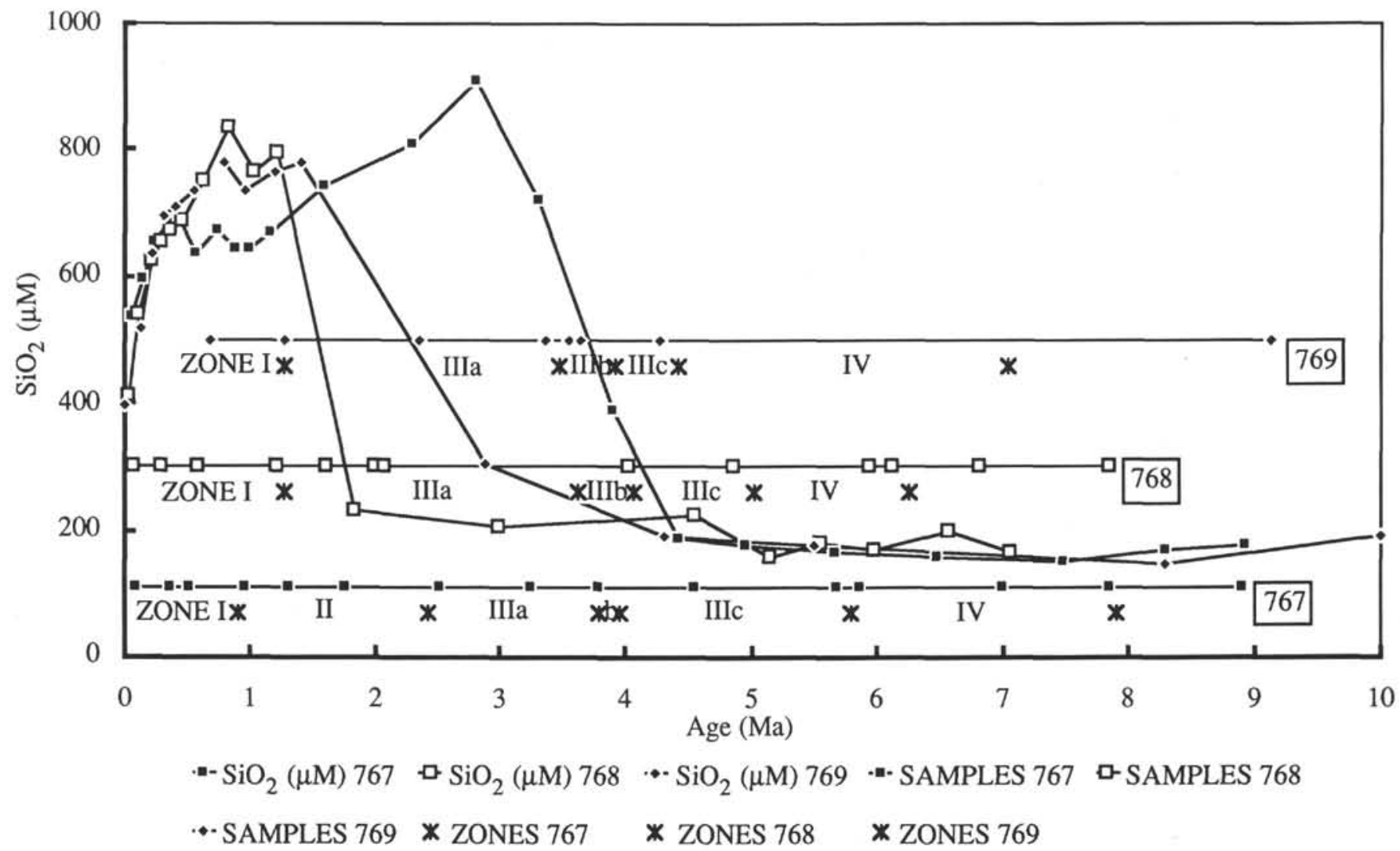

Figure 4. Plot of dissolved silica vs. age (Interstitial water analyses: Rangin, Silver, von Breymann, et al., 1990) showing relationship between concentration gradients and diagenetic zones. 

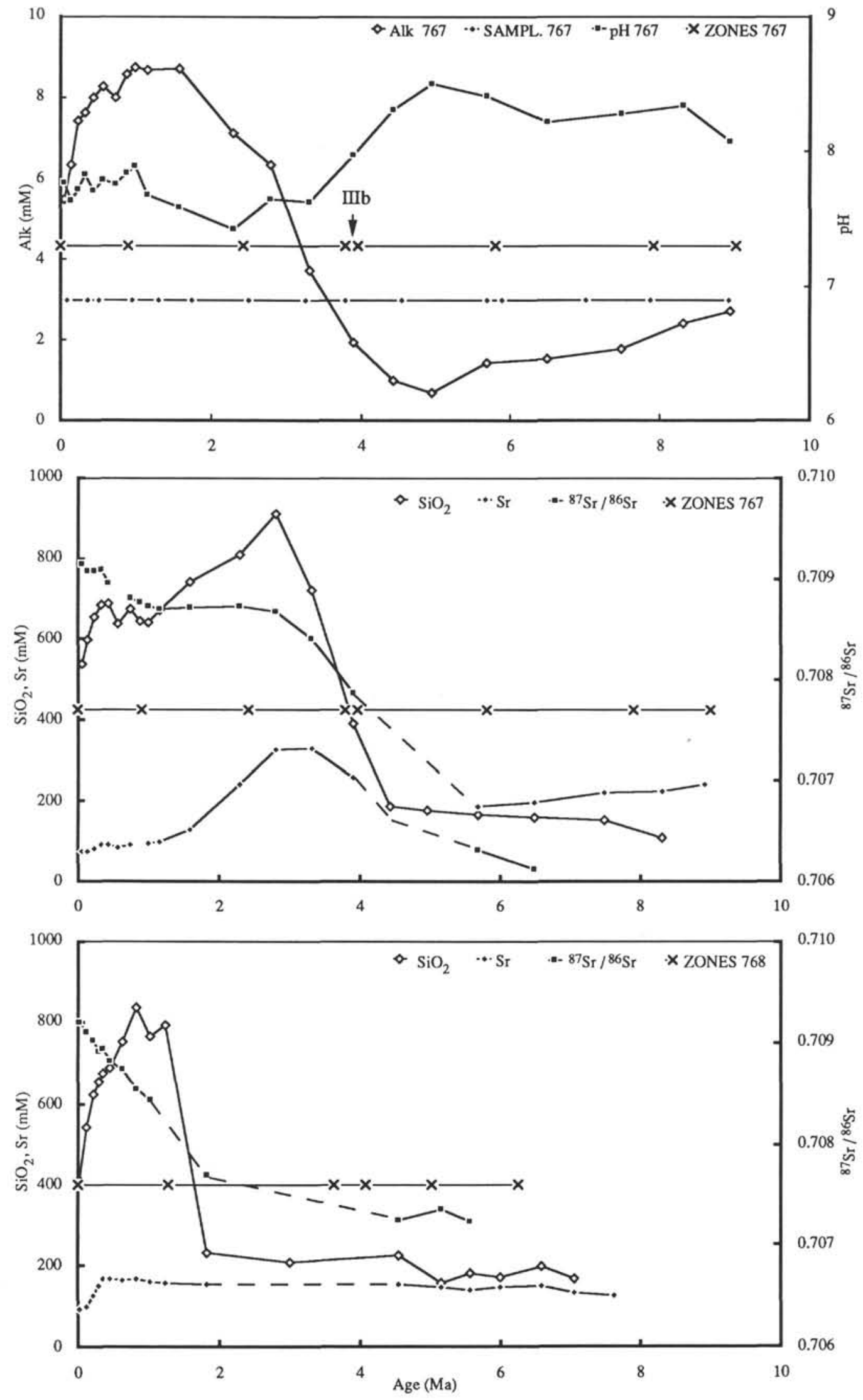

Figure 5. Strontium isotopic composition, alkalinity, $\mathrm{pH}$, dissolved silica, and strontium contents of the pore fluids vs. age (interstitial water analyses: Rangin, Silver, von Breymann, et al., 1990; von Breymann et al., this volume), and location of diagenetic zones. 


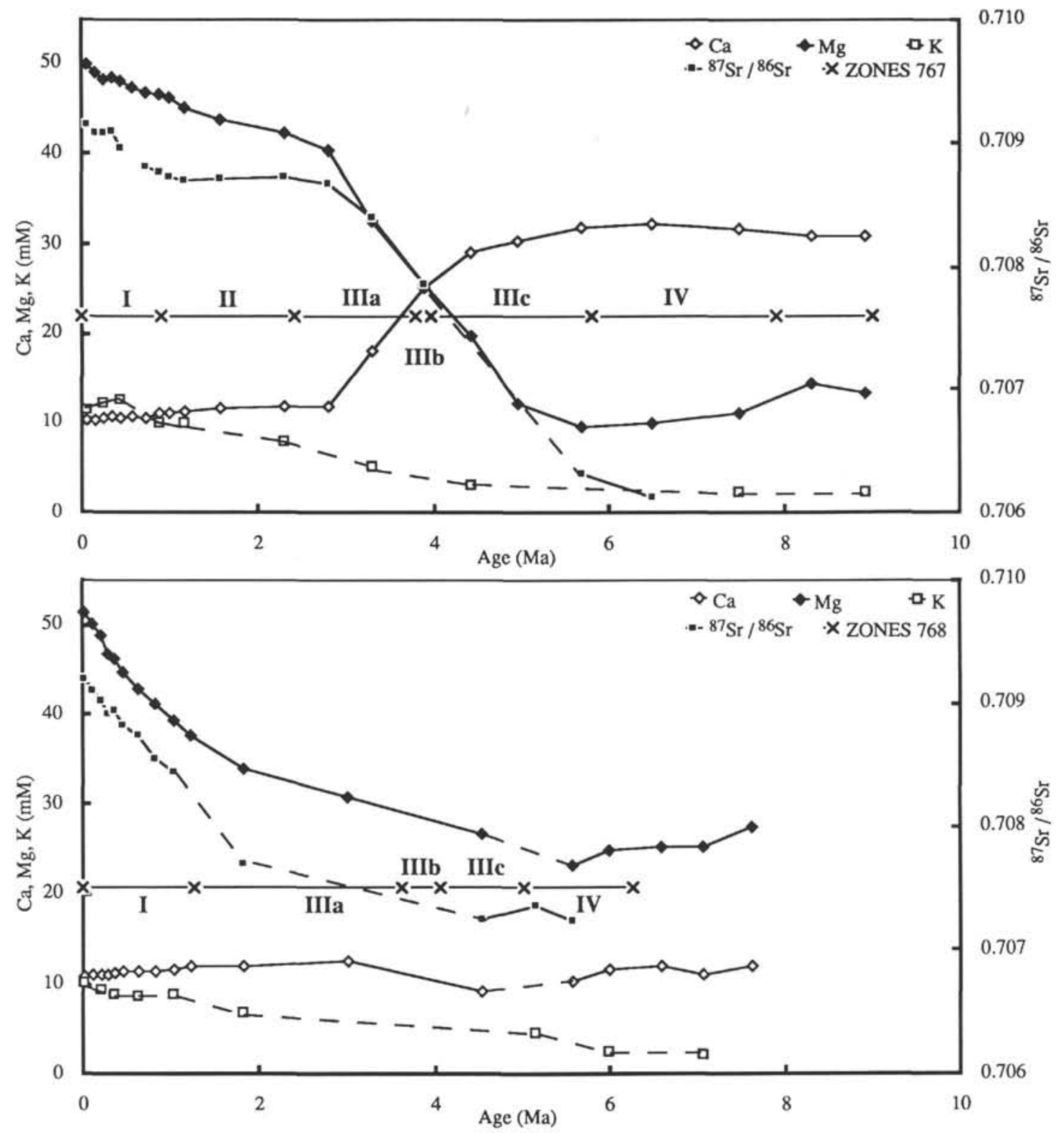

Figure 6. Strontium isotopic composition, dissolved calcium, magnesium, and potassium contents of the pore fluids vs. age (interstitial water analyses: Rangin, Silver, von Breymann, et al., 1990; von Breymann et al., this volume), and location of diagenetic zones. 

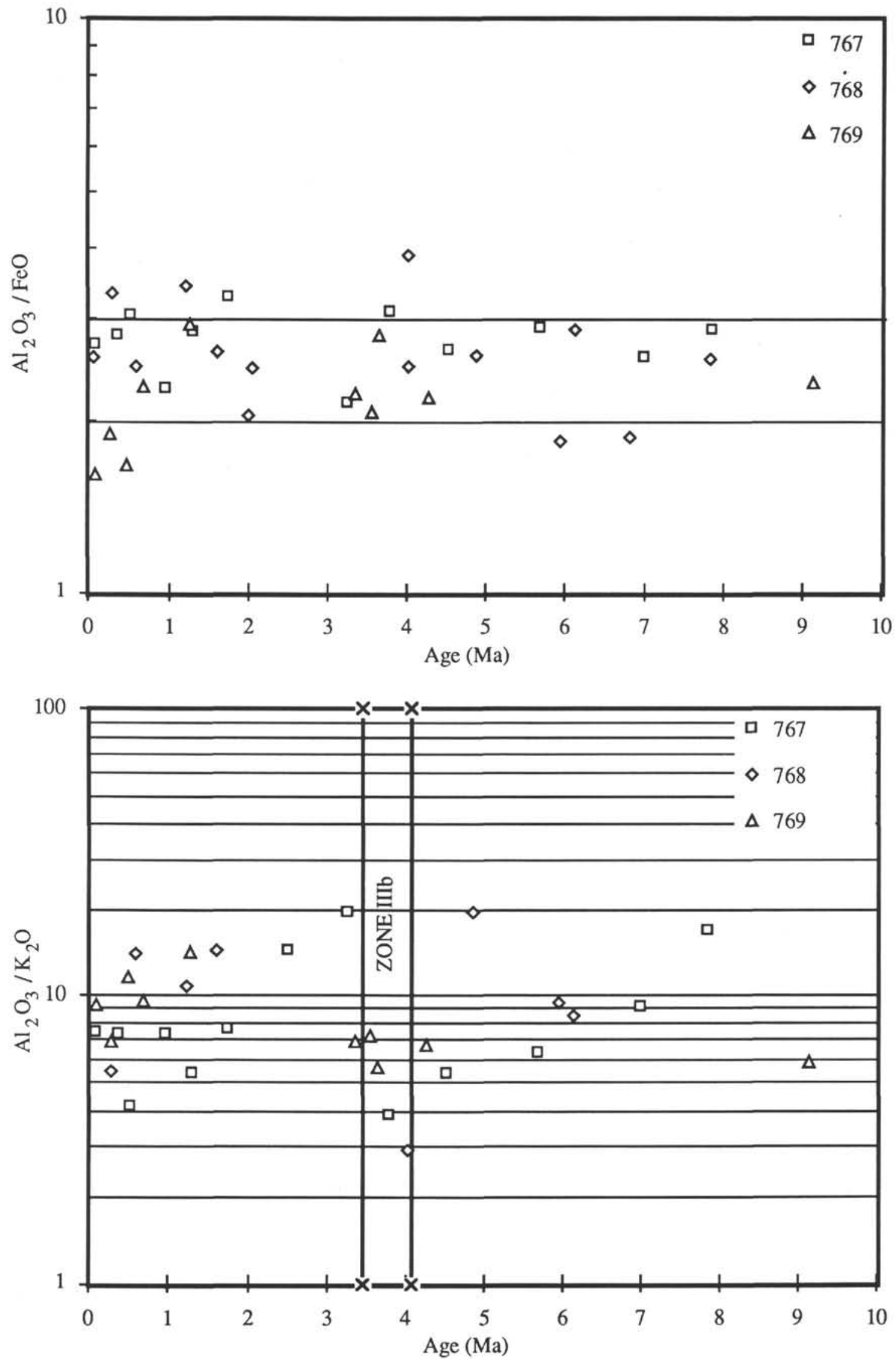

Figure 7. $\mathrm{Al}_{2} \mathrm{O}_{3} / \mathrm{K}_{2} \mathrm{O}$ and $\mathrm{A1}_{2} \mathrm{O}_{3} / \mathrm{FeO}$ ratios vs. time respectively, given by the $35-$ through $63-\mu \mathrm{m}$ fraction and bulk chemical analyses of ash layers samples. 
Table 5. Oxygen isotope data for glasses, clay minerals, and zeolite.

\begin{tabular}{|c|c|c|c|}
\hline Hole & $\begin{array}{l}\text { Core, section, } \\
\text { interval }(\mathrm{cm})\end{array}$ & Nature & $\begin{array}{l}\delta^{18} \mathrm{O} \% \\
\text { SMOW }\end{array}$ \\
\hline $767 \mathrm{~B}$ & $4 \mathrm{H}-6, \quad 41-43$ & Fresh glass & 9.0 \\
\hline 767B & $29 X-2,117-119$ & Altered glass & 12.4 \\
\hline 767B & $26 \times-5, \quad 44-46$ & Phillipsite & 24.5 \\
\hline $768 B$ & $4 \mathrm{H}-5$, & Detrital clay & 17.6 \\
\hline 767B & $35 X-5$ & Altered glass and authigenic smectite & 22.8 \\
\hline $767 \mathrm{~B}$ & $26 X-5$ & Authigenic smectite & $26.1-26.3$ \\
\hline $768 \mathrm{~B}$ & $18 \mathrm{H}-6$ & Authigenic smectite & 26.5 \\
\hline $767 B$ & $42 X-6$ & Authigenic smectite & 24.9 \\
\hline
\end{tabular}

